\title{
A home - made purge and trap - thermos desorption - gas chromatograph coupled with atomic fluorescence detector for the determination of ultra - trace methylmercury
}

\author{
Le Thi Huynh Mai, Nguyen Cong Hau, Huynh Quan Thanh, Nguyen Van Dong*
}

\begin{abstract}
A hyphenated system for methylmercury based on a gas chromatograph (GC) coupled with an atomic fluorescence spectrometric (AFS) detector equipped with an online purge and trap as a preconcentrator was made. Operating parameters for the whole system were optimized and analytical performances of the system are verified by quality control chart for stability. Organomercurial compounds in an aqueous sample were in-situ ethylated and purged to a trap in-line with a separation device instead of conventional off-line solvent extraction. A $100 \mathrm{~mL}$ aqueous sample containing methylmercury in an impinger was mixed with sodium tetraethylborate at pH 5.0. The forming volatile ethylmethylmercury was purged for 30 minutes with the assistance of an Ar flow and trapped into a Tenax sorbent. The trap was then heated to release volatile compounds including ethylmethylmercury into a GC-AFS for separation and detection. The instrumental detection limit was $4.8 \mathrm{pg} \mathrm{Hg} / \mathrm{L}$. The method can therefore be applied for the determination of methylmercury in water samples at ultra - trace.
\end{abstract}

Index Terms-Gas chromatography, atomic fluorescence detector, methylmercury, purge and trap, ultra - trace levels

\section{INTRODUCTION}

M ercury $(\mathrm{Hg})$ is one of the most serious global pollutants that affects human and ecosystem health. Mercury is a naturally occurring element, but has been directly mobilized by humans for thousands of years into aquatic and

Received: 08-11-2017, accepted: 14-5-2018, published: 129-2018

Author: Le Thi Huynh Mai, Nguyen Cong Hau, Huynh Quan Thanh, Nguyen Van Dong - VNUHCM, University of Science - winternguyenvan@gmail.com terrestrial ecosystems through mining process, the use of mercury in precious metal extraction, the burning of fossil fuels (e.g., coal, oil, natural gas), and its use in products (e.g., paint, electronic devices) and by industrial activities (chlor-alkali plants, as a catalyst) [1]. In natural water, the main $\mathrm{Hg}$ species are elemental $\left(\mathrm{Hg}^{0}\right)$, inorganic $\left(\mathrm{Hg}^{2+}\right)$ and alkylmercury compounds such as monomethylmercury $[\mathrm{CH} 3 \mathrm{Hg}+]$, dimethylmercury $\left[\left(\mathrm{CH}_{3}\right)_{2} \mathrm{Hg}\right]$, and aryl compounds [e.g., phenylmercury]. Monomethylmercury is commonly referred to as methylmercury ( $\mathrm{MeHg}$ ) [2]. Methylmercury is by far the most toxic and most commonly occurring organic mercury compounds. Mercury species exist in natural water at extremely low concentrations. Typically, $\mathrm{MeHg}$ represents less than $10 \%$ of the total $\mathrm{Hg}$ in surface waters, but can exceed $30 \%$ in perturbed systems such as newly formed reservoirs. In natural surface waters (freshwater and marine), concentrations of total mercury range from under 1 to $20 \mathrm{ng} / \mathrm{L}$ while concentrations of $\mathrm{MeHg}$ are usually less than 1 ng/L [2]. However, methylmercury can be bioaccumulated and biomagnified in the food chain by factors of up to 106-107 times [3]. $\mathrm{MeHg}$ exposure can be important to the people who rely on marine fish and mammals for a majority of their protein and nutrition. Exposure to high levels of methylmercury has been found to cause neurological damage, as well as fatalities, among adults. Prenatal life and small children are even more susceptible to brain damage due to their enhanced sensitivity to the neurotoxin. The most well documented cases of severe methylmercury poisoning were from Minamata Bay, Japan in 1956 (industrial release of methylmercury) [4] and 
in Iraq in 1971 (wheat treated with a methylmercury fungicide) [5]. In each case, hundreds of people died, and thousands were affected, many with permanent damage. Therefore, much effort has been expended in determining the methylmercury in environmental samples. Some of the most common methods in determination of methylmercury are LC - ICPMS [6], GC - ICPMS [7], GC - QT - AAS, GC - MIP - AES [8] and GC - AFS [7]. GC - AFS has been still commonly used for methyl mercury analysis, mainly owing to its high sensitivity comparable to GC-ICPMS and low cost. This technique is properly possible to be conducted in Vietnam. Preconcentration is the most important factor in determining methylmercury due to its extremely low concentration in water sample. Preconcentration on resin, by extraction, purge and trap and capillary electrophoresis have been reported. For low level $\mathrm{CH}_{3} \mathrm{Hg}^{+}$analysis, the most widely used technique is purge and trap gas chromatography (GC) coupled with an element specific detector, such as atomic fluorescence spectrometry (AFS) or inductively coupled plasma mass spectrometry (ICPMS).

The technique purge and trap was used in this research to enrich methylmercury prior to the separation step in the GC. This method described in this report was based on EPA 1630. This technique not only provides enough the sensitivity but also simple operation and low cost compared to other modern and complicated methods, such as ICPMS.

\section{MATERIALS AND METHODS}

\section{Reagents, standard solutions}

All solutions were prepared in double distilled, de-ionized water. $\mathrm{HNO}_{3}(65-67 \%), n$ hexane, $\mathrm{CH}_{3} \mathrm{HgCl} \quad(\mathrm{MeHgCl}), \quad \mathrm{Hg}\left(\mathrm{NO}_{3}\right)_{2}$, dichloromethane (DCM), tetrahydrofuran (THF), $\mathrm{CH}_{3} \mathrm{COOH}$ glacial and $\mathrm{CH}_{3} \mathrm{COONa}$. These chemicals were of analytical - reagent grade and were obtained from Merck. Argon $99.999 \%$ (v/v) was purchased from Singapore Industrial Company. $\mathrm{MeHgEt}$ and $\mathrm{Et}_{2} \mathrm{Hg}$ standard solutions were prepared by the ethylation reaction of $\mathrm{MeHgCl}, \mathrm{Hg}^{2+}$ and $\mathrm{NaBEt}_{4}$. The purity of these solutions was checked by GC-AFS and standardized by FIMS 100 system (Perkin Elmer).
Ethylation reagent was prepared by dissolution of $1 \mathrm{~g}$ sodium tetraethylborate (Sigma-Aldrich) in $100 \mathrm{~mL} \mathrm{2 \%} \mathrm{KOH} \mathrm{(Merck)} \mathrm{in} \mathrm{Ar} \mathrm{atmosphere} \mathrm{and}$ kept in a $-18^{\circ} \mathrm{C}$ freezer for long-term storage (up to 6 months).

Since ethylmethylmercury and diethylmercury standards have not been commercially available, the preparation of the standards were carried out as previously described [9]. The purity of these solutions was tested by GC - AFS and the concentrations of the compounds were verified by FIMS 100 system. The standards were stored at $20{ }^{\circ} \mathrm{C}$ for analysis.

\section{Instrumentation}

A GC Varian 3300 is equipped with an "on column" injector and a capillary DB-1 column (10 $\mathrm{m} \times 0.53 \mathrm{~mm}$ i.d. $\times 2.65 \mu \mathrm{m}$, Supelco, USA) connected with a HP-1 (15 m x $0.53 \mathrm{~mm}$ i.d. x 1.5 $\mu \mathrm{m}$, Supelco, USA). The injector and the oven were

$$
\begin{aligned}
& 40^{\circ} \mathrm{C} \stackrel{100^{\circ} \mathrm{C} / \mathrm{min}}{\longrightarrow} 200^{\circ} \mathrm{C}(4 \mathrm{~min}) \\
& 40^{\circ} \mathrm{C}(1 \mathrm{~min}) \\
& \stackrel{20^{\circ} \mathrm{C} / \mathrm{min}}{\longrightarrow} 120^{\circ} \mathrm{C}(1 \mathrm{~min}) \stackrel{\mathrm{a} 0^{\circ} \mathrm{C} / \mathrm{min}}{\longrightarrow} 200^{\circ} \mathrm{C}(1 \mathrm{~min})
\end{aligned}
$$

; respectively. The AFS detector (PS Analytical) was operated at a "make - up" gas flow rate of 220 $\mathrm{mL} / \mathrm{min}$ and a sheath gas flow rate of $190 \mathrm{~mL} / \mathrm{min}$. A home-made interface between the GC and the AFS detector consisted of a pyrolyser oven maintaning at $540{ }^{\circ} \mathrm{C}$ for mercury atomization. The purge and trap system consists of a flow controller for purge gas, a $150 \mathrm{~mL}$ impinger with a sintered glass porous scrubber and a magnetic stirring bar, a Nafion tubing to remove water from purged gas stream and a quartz tube $(15 \mathrm{~cm} \times 0.25 \mathrm{~cm}$ id $\times 0.5$ $\mathrm{cm}$ od) packed with $200 \mathrm{mg}$ Tenax sorbent. The thermodesorption device consists of a quartz tube (12 cm long, $3 \mathrm{~cm}$ id) housing a spiral $10 \Omega \mathrm{Ni}-\mathrm{Cr}$ resistance wire supplied by a $24 \mathrm{~V}$ transformer. The temperature of the thermodesorption device was controlled by a PID controller via a thermocouple located on the surface of the Tenax trap.

\section{Sample collection}

Water samples were collected by directly filling the $1 \mathrm{~L}$ PTFE container bottles from the rain water and river water at Binh Khanh Ferry Station. Samples were kept away from sunlight and stored 
at ambient temperature for transportation. The samples were filtered through GFF $(0.45 \mu \mathrm{m} \times 47$ $\mathrm{mm}$, Supelco) or GFF $(0.7 \mu \mathrm{m} \times 47 \mathrm{~mm}$, Whatman) membrane and stored at $-20{ }^{0} \mathrm{C}$ for further analysis.

\section{Fabrication of the purge\&trap - thermodesorption - chromatograph coupled} with atomic fluorescence detector (PT-GC-AFS)

\section{Gas de-humidifer}

The sample gas stream containing the analytes with high humidity and the dried gas stream were setup to flow in countercurrent for the best dehumidifying efficiency. This was arranged with a tube-in-tube model, in which a Nafion tubing (2 $\mathrm{mm}$ id) was put inside a polypropylene tubing (6 $\mathrm{mm}$ id). The sample gas stream moved inside the Nafion tubing and the drier gas moved ouside the Nafion tubing (Fig. 1).

In this study, the Nafion tubing was $2.0 \mathrm{~m}$ long, $1.2 \mathrm{~mm}$ inner diameter which tolerates for a gas flow rate up to $200 \mathrm{~mL} \cdot \mathrm{min}^{-1}$ and the flow rates of compressed air from 0.5 to $2.5 \mathrm{~L} / \mathrm{min}$ were used.

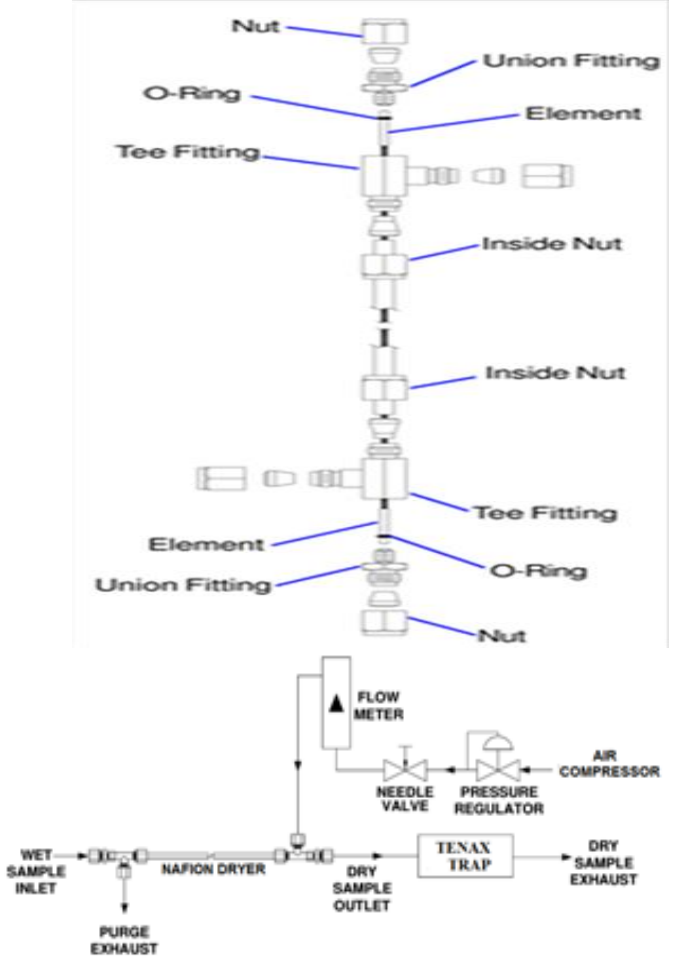

Fig. 1. (a) a broken Tenax trap and (b) a typical setup for a humidifier system with Nafion tubing

Sample purging vessel
The purging vessel used in this study was a 150 $\mathrm{mL}$ - impinger equipped with a very fine porous glass scrubber which generates very tiny gas bubbles to maximize the gas-liquid diffusion.

The mixing was enhanced with a magnetic stirrer. The impinger allowed the sample volume up to $100 \mathrm{~mL}$ thus provided better detection limit. The flow rate of purge gas was an another important factor. The higher the flow rate was, the better efficiency of the purging achieved. However, the inner diameter of the Nafion (dehumidifier) tubing and the dimension of the Tenax trap were the limiting factors.

\section{Trap and thermal desorption}

Tenax TA material was used as a sorbent to trap dialkylmercury compounds. Approximately 200 mg Tenax TA was loaded into a quartz tube (i.d. 3 $\mathrm{mm}$ and o.d. $5 \mathrm{~mm}$ ). Glass wool was plugged at the two sides of the Tenax material to fix the sorbent under the pressure of a purged gas through the trap. The trap was connected with a needle via a Teflon adapter. This device facilitated the transfer of carrier gas and desorbed substances from the trap to GC column. The trap was placed in the center of a spiral resistance wire. This resistance wire ensured that within 3 minutes, its inner space reached $150^{\circ} \mathrm{C}$ if a voltage of $24 \mathrm{~V}$ was applied. Teflon membane and electrical tape were used to keep the fitting tight and free from gas leak (Fig. 2).

The home-made PT-GC-AFS system was a combination of the impinger, the Tenax trap, the thermodesorption and the GC-AFS (Fig. 3).

\section{Procedure for in-situ ethylation and purge \& trap}

$100 \mathrm{~mL}$ aqueous solution spiked with $<10 \mathrm{pg}$ methylmercury (as $\mathrm{Hg}$ ) was transferred into the impinger vessel. A portion of $3 \mathrm{~mL}$ buffer solution $\mathrm{pH} 4.8$ made of acetic acid/sodium acetate $3 \mathrm{M}$ and $50 \mu \mathrm{L} \mathrm{NaBEt}_{4} 1 \%$ were subsequently added to this vessel. The mixture was magnetically stirred for 3 minutes for the ethylation reaction to occur. The volatile ethylated mercury compounds in the aqueous were purged then trapped on a Tenax TA sorbent for $30 \mathrm{~min}$. The Tenax trap was then mounted on the thermodesorption device with its needdle inserted into the GC injector. The thermodesorption device was heated and 
maintained at $150^{\circ} \mathrm{C}$ for $10 \mathrm{~s}$. The alkylated mercury species were desorbed and swept with purified argon stream at a flow rate of $50 \mathrm{~mL} / \mathrm{min}$ to the injector. The analytes were then separated
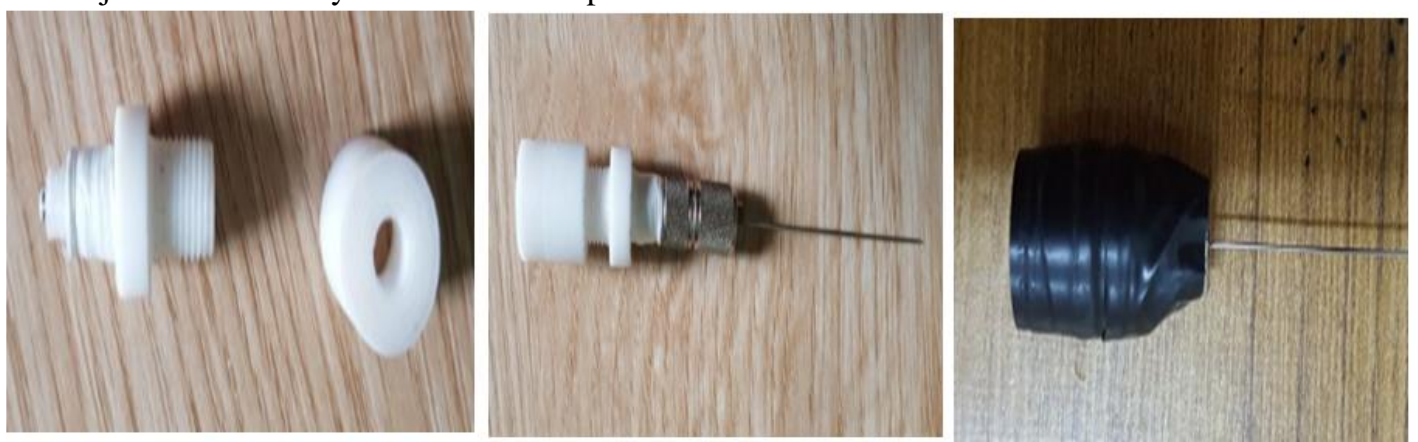

Fig 2. Home-made Tenax trap - GC

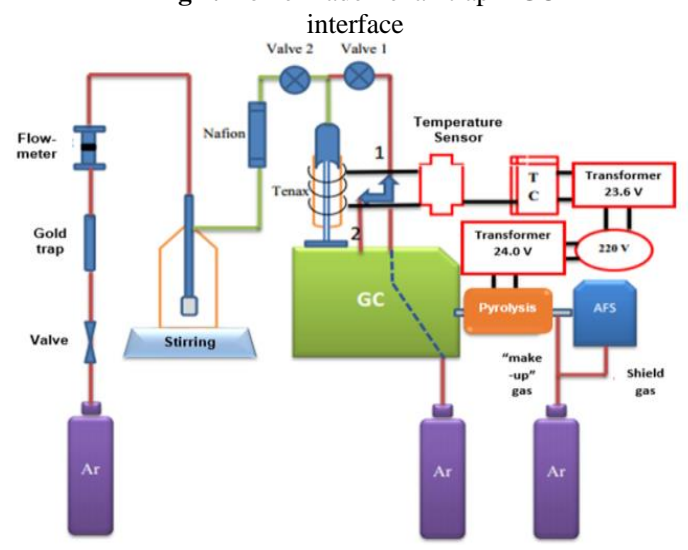

Fig 3. Diagram of PT-GC-AFS

\section{RESULTS AND DISCUSSION}

Optimisation of the working parameters for GC-AFS

The working parameters for the gas chromatograph, the pyrolyzer and the make-up and shealth flow rates AFS detector were re-optimized based on previous studies for maximum sensitivity and best resolution [9].

In this study, argon was used as both "make-up" gas and sheath gas.

Table 1. Optimized parameters of the GC-AFS

\begin{tabular}{|l|l|l|}
\hline Apparatus & Parameters & $\begin{array}{l}\text { Optimized } \\
\text { conditions }\end{array}$ \\
\hline GC & Carrier gas & $22.7 \mathrm{~cm} / \mathrm{s}$ \\
\hline Pyrolyzer & Temperature & $540^{\circ} \mathrm{C}$ \\
\hline \multirow{2}{*}{ AFS detector } & "Make-up" gas & $220 \mathrm{~mL} / \mathrm{min}$ \\
\cline { 2 - 3 } & Sheath gas & $190 \mathrm{~mL} / \mathrm{min}$ \\
\hline
\end{tabular}

A test run with a mixed standard containing $\mathrm{MeHgEt}$ and $\mathrm{Et}_{2} \mathrm{Hg}$ in hexane (Fig. 4) showed that the GC-AFS system worked properly.

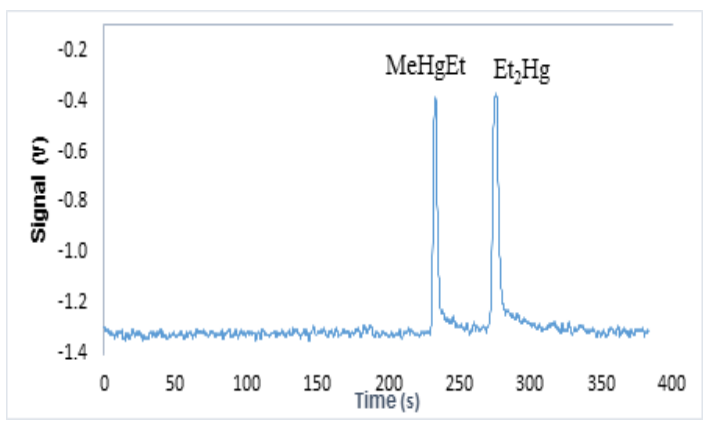

Fig 4. Chromatogram of $\mathrm{MeHgEt}\left(5.501 \mathrm{pg} \mathrm{Hg}\right.$ ) and $\mathrm{Et}_{2} \mathrm{Hg}$ (5.045 pg Hg) on GC - AFS system

\section{Calibration curves on GC-AFS}

Linear calibration curves (Fig. 5) for $\mathrm{MeHgEt}$ and $\mathrm{Et}_{2} \mathrm{Hg}$ were $\mathrm{I}_{\mathrm{FL}}=0.4574 \mathrm{~m}_{\mathrm{Hg}(\mathrm{MeEtHg})}-0.0552$ $\left(\mathrm{R}^{2}=0.9998\right)$ and $\mathrm{I}_{\mathrm{FL}}=0.3709 \mathrm{~m}_{\mathrm{Hg}(\mathrm{Et} 2 \mathrm{Hg})}+0.0942$ 
$\left(R^{2}=0.9992\right)$ of which both were linear between 2 and $12 \mathrm{pg} \mathrm{Hg}$.

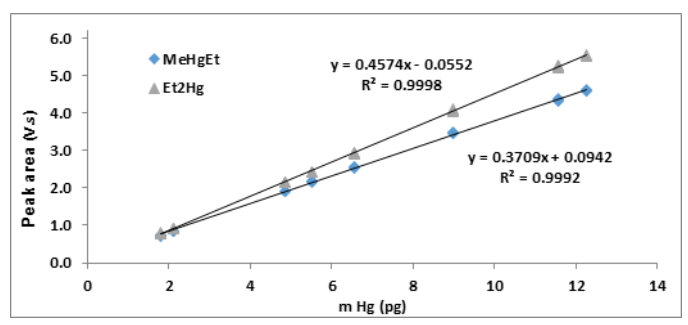

Fig. 5. Calibration curves of $\mathrm{MeHgEt}$ and $\mathrm{Et}_{2} \mathrm{Hg}$

\section{Water elimination from sample gas stream}

Along the excitation and emisson processes occuring in atomic fluorescence, quenching process must be taken into consideration because it reduces and in many cases eliminates the fluorescent signal. The quenching process is governed by the type of carrier and sheath gas used. The order of quenching efficiencies for some common gases is $\mathrm{Ar}<\mathrm{H}_{2}<\mathrm{H}_{2} \mathrm{O}<\mathrm{N}_{2}<\mathrm{CO}<\mathrm{O}_{2}<$ $\mathrm{CO}_{2}$. Among them, water vapour is one of the most serious quenching agent since it is generated at large quantities and accompanied with ultratrace ethylmethylmercury [10]. Furthermore, water vapour could hinder the retention of ethylmethylmercury on the Tenax trap. At ultratrace mercury levels, the hydration should be effective and be free from contamination and loss of the analyte as well as maintain the intergrity of the analyte. Nafion is the most appropriate dehumidifier material for the requirement.

Nafion is a copolymer of tetrafluoroethylene (Teflon) and perfluoro-3,6-dioxa-4-methyl-7octenesulfonic acid. Like Teflon, Nafion is highly resistant to chemical attack, and the presence of exposed sulfonic acid groups make Nafion tube excellent in dehydration. Nafion removes water by the exchange of water vapour from the gas stream with high humidity at one side through the membrane to low humidity gas stream (drier gas) at the other side of the membrane. The exchange rate follows as the first order kinetic reaction, the equilibrium is therefore reached quickly (in miliseconds). The exchange is quite selective for water vapour, other chemical compounds in the gas stream are usually unaffected. The drier gas was compressed air offered low humidity, high flow rate and low cost (compared to $\mathrm{N}_{2}$ or Ar).

Two separate experiments were conducted for the optimisation of the device. In the first test, 100
$\mathrm{mL}$ of water was purged continuously in 40 minutes with the aid of a flow of $250 \mathrm{mLmin}^{-1}$ argon through a moisture trap containing an exact amount of $\mathrm{Mg}\left(\mathrm{ClO}_{4}\right)_{2}$. When the purging was completed, the trapped water on $\mathrm{Mg}\left(\mathrm{ClO}_{4}\right)_{2}$ was determined to be $1.08 \mathrm{~g}$ for a purging time of 40 minutes. The amount of water in the purged gas seriously deteriorated the baseline of the atomic fluorescence for mercury (Fig. 6). In the second test, a Nafion tubing was connected in front of the $\mathrm{Mg}\left(\mathrm{ClO}_{4}\right)_{2}$ moisture trap and a compressed dry air flow rates varying from 0.5 to $2.5 \mathrm{~L} \cdot \mathrm{min}^{-1}$. The gain in weight of $\mathrm{Mg}\left(\mathrm{ClO}_{4}\right)_{2}$ trap was not so much (about $0.0037 \mathrm{~g}$ ) for the tested flow rates of dry air. This indicated that Nafion tube was efficient in removing water from the sample stream. The efficiency of Nafion was also verified by the AFS detector. Fig. 6 revealed that beside a slight increase in signal due to drift in the detector, no distortion of fluorescent signal caused by water vapour was detected. According to the producer's recommendation, the drying gas flow rates should be used in a range of 1.5-2.0 L.min ${ }^{-1}$.

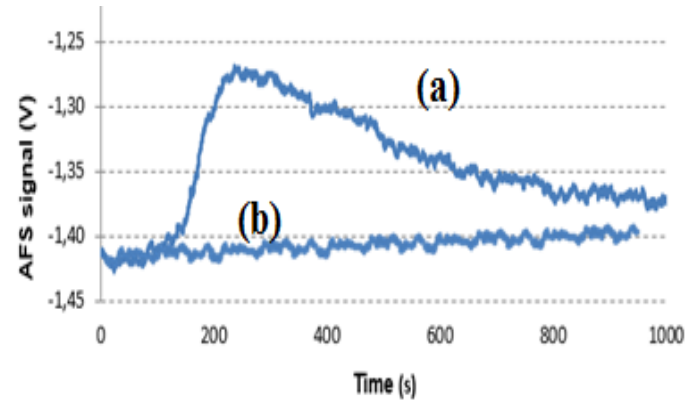

Fig 6. Background signals (a) without Nafion tube and (b) with Nafion tube (drying gas $0.5-2.5$ L.min ${ }^{-1}$ )

\section{Purge gas flow rate and purging time}

The following aspects should be taken into consideration prior to optimizing the flow rate of the purge gas: the capacity of Nafion tubing, the back-pressure of the Tenax trap and it's breakthrough volume for alkylated mercury compounds. The manufacturer has recommended that the maximum flow rate that could be applied to the Nafion tubing TT-50 is not higher than 250 $\mathrm{mL} / \mathrm{min}$. This limited pressure is to assure the Nafion tubing is not broken during operation. Generally, the higher flow rates of the purging gas, the higher back-pressure applied on the sorbent that could make the trap destroyed and also the lower breakthough volume. In our system, the 
most relevant flow rates for the stable operation of the purge \&trap system was 160 and $180 \mathrm{~mL} / \mathrm{min}$.

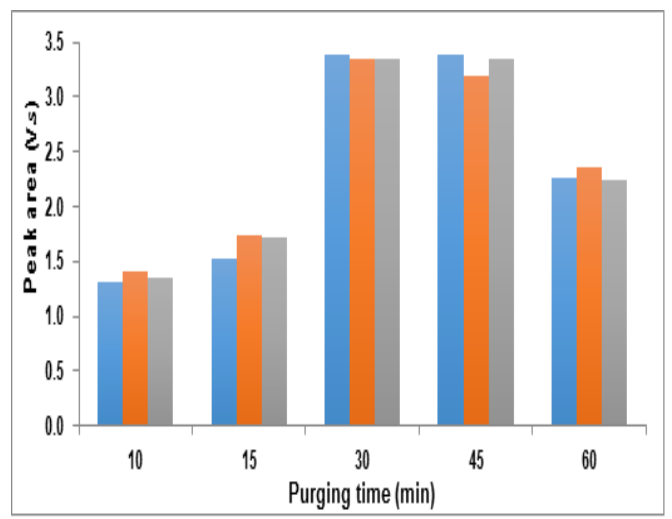

Fig.7. Purging time vs peak area of $5 \mathrm{pg} \mathrm{MeHg}$ (as $\mathrm{Hg}$ ) Purging time is another important factor that had to be concerned because there was no internal standard used to make sure that this process is reproducible. The results (Fig. 7) showed that at purging flow rate of $180 \mathrm{~mL} \cdot \mathrm{min}^{-1}$, the purge\&trap of ethylmethyl mercury reach the maximum for the purging times between 30-45 minutes. Off this range, the purge\&trap efficiency for ethylmethyl mercury was low. A purging time less than 30 minutes was not long enough to evaporate all ethylmethyl mercury from the bulb sample solution. A purging time longer than 45 minutes made the purging gas exceeded the breakthough volume of the trap resulting to the elution of ethylmethyl mercury from the sorbent. The relevant purging time should therefore be varied within 30 and 45 minutes to make sure that the ethylmethyl mercury is efficiently evaporated from the sample and retained on the Tenax trap.

\section{Trap and thermodesorption}

The trap was not linked with GC column when the accumulation process was taking place. After the trapping period completed, the syringe - head (Fig. 8) was then connected to the Tenax tube and injected to GC system by thermal desorption of the trap. When the injection was completed, the whole trap system (Fig.8a) was then moved out of the GC injector to wait for the following sample.

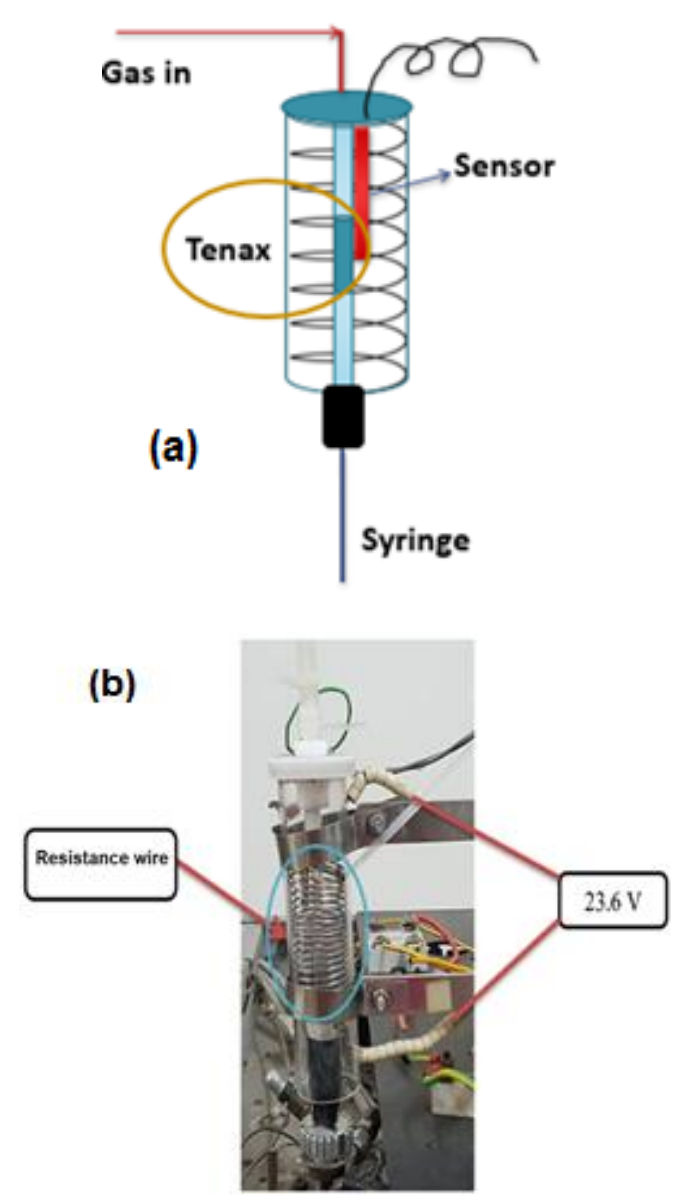

Fig. 8. Tenax trap (a), thermal desorption device (b)

\section{LOD and LOQ estimation}

Limit of detection (LOD) and limit of quantitation (LOQ) were estimated as three and ten times the standard deviation of the eleven blanks spiked with small amounts of $\mathrm{MeHg}$, respectively (Fig. 9). Limit of detection and quantitation were estimated as $0.48 \mathrm{pg} \mathrm{Hg}$ and $0.76 \mathrm{pg} \mathrm{Hg}$, respectively corresponding to $4.8 \mathrm{ppq}$ and $7.6 \mathrm{ppq}$ $\mathrm{Hg}$ for the purging volume of $100 \mathrm{~mL}$.

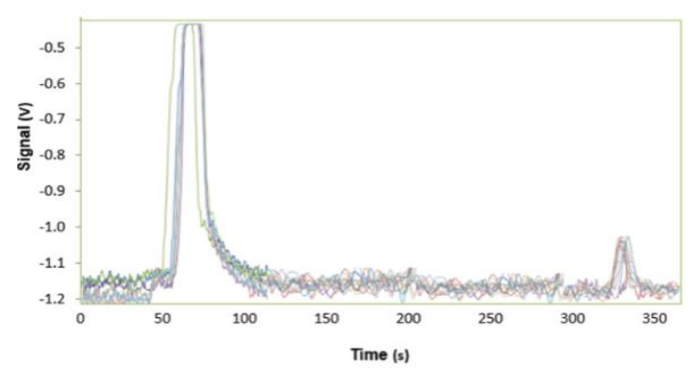

Fig 9. Overlaid chromatograms of 11 blanks spiked with $1 \mathrm{pg} \mathrm{MeHg}$ 
Calibration curve on purge and trap - GC AFS

Calibration curves for $\mathrm{MeHg}$ including 8 standards (0.65 pg, $1.18 \mathrm{pg}, 3.25 \mathrm{pg}, 4.87 \mathrm{pg}, 6.49$ $\mathrm{pg}, 11.37 \mathrm{pg}, 14.13 \mathrm{pg}$ and $16.24 \mathrm{pg}$ as $\mathrm{Hg}$ ) of analyte were prepared. All intensities (as peak height or peak area) were corrected with blank and the sensitivity of the instrument was calculated using the data from which the linear calibration curve was achieved (Fig. 10).

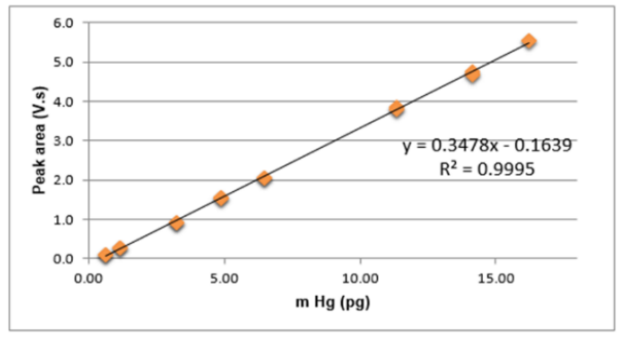

Fig. 10. Calibration curve on PT- GC - AFS system

\section{System quality control}

The PT-GC-AFS system was daily checked using a newly prepared $8 \mathrm{pg} \mathrm{MeHg}$ standard (as $\mathrm{Hg}$ ) for 20 consecutive working days. The control chart (Fig. 11) showed that the operating parameters for the home-made PT-GC-AFS were successfully controlled.

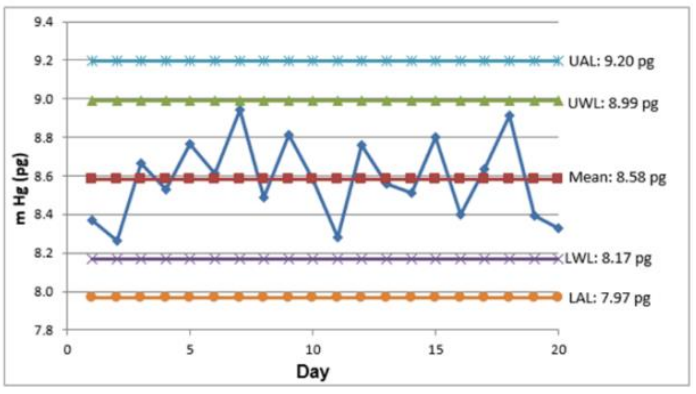

Fig. 11. Quality control chart for $\mathrm{MeHg}$ analysis in the homemade PT-GC-AFS.

Application to water samples prepared from rain water and river water

The PT-GC-AFS was used to preliminarily determined $\mathrm{MeHg}$ in some water samples containing low matrices contents such as rain water and river water. Each sample was conducted repeatedly 5 times using the home-made PT - GC - AFS system (Fig. 12). The samples were also spiked with methylmercury for recovery test and matrix inteference check. No matrix inteference was observed for the MeHg analysis with the PTGC-AFS. The concentration of $\mathrm{MeHg}$ in the rain water sample was below the detection limit while it was $0.0730 \pm 0.0022 \mathrm{ppt}$ for the river water sample.

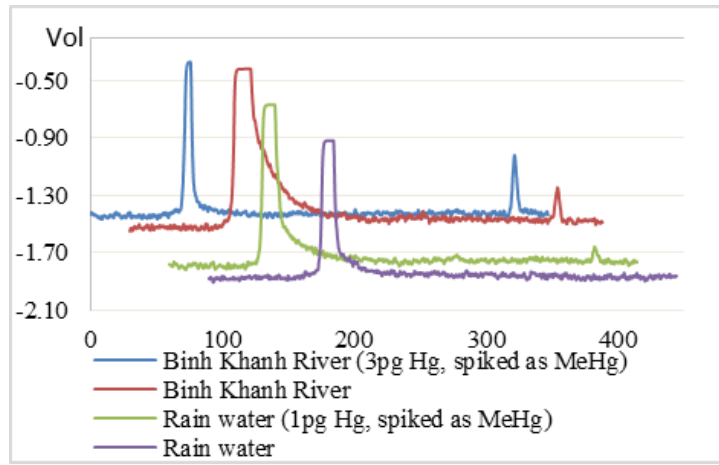

Fig. 12. Typical chromatograms for $\mathrm{MeHg}$ analysis in rain and river water samples. The chromatograms are offset for clarity

\section{CONCLUSION}

A home-made purge\&trap and thermodesorption - GC-AFS for the detemination of $\mathrm{MeHg}$ at ultra-trace levels was successfully fabricated. This hyphenated system offers a range of advantages such as low cost, simple operation, high sensitivity and good reproducibilty compared to the state of the art ICP - MS. The system can be used to analyze $\mathrm{MeHg}$ in natural waters samples.

\section{REFERENCES}

[1]. C.T.M. Driscoll, P. C. Robert, J.M. Hing, P.J. Daniel, Mercury as a global pollutant: sources, pathways, and effects. Environmental Science \& Technology, 47, 10, 4967-4983, 2013.

[2]. N.R.G. Marine, "Canadian Water Quality Guidelines for the Protection of Aquatic Life." Canadian Council of Ministers of the Environment, Winnipeg, 1-5, 1999.

[3]. K. Leopold, M. Foulkes, P.J. Worsfold, Preconcentration techniques for the determination of mercury species in natural waters. TrAC Trends in Analytical Chemistry, 28(4), 426-435 (2009).

[4]. F.M. Ditri, Mercury contamination - what we have learned since Minamata. Environmental Monitoring and Assessment, 19, 1-3, 165-182, 1991.

[5]. F.D. Bakir,S.F. Amin-Zaki, L. Murtadha, M. Khalidi, A. Al-Rawi, N.Y. Tikriti, S. Dhahir, H.I. Clarkson, T.W. Smith, Methylmercury poisoning in Iraq. Science, 181, 4096, 230-241, 1973.

[6]. B. Vallant, R. Kadnar, W. Goessler, Development of a new HPLC method for the determination of inorganic and methylmercury in biological samples with ICP-MS detection, Journal of Analytical Atomic Spectrometry, 22, 322-25, 2007. 
[7]. H.L. Armstrong, W.T. Corns, P.B. Stockwell, G. O'Connor, L. Ebdon, E.H. Evans, Comparison of AFS and ICP-MS detection coupled with gas chromatography for the determination of methylmercury in marine samples, Analytica Chimica Acta, 390, 1, 245-253, 1999.

[8]. J. Qian, U. Skyllberg, Q. Tu, W.F. Bleam, W. Frech, Efficiency of solvent extraction methods for the determination of methyl mercury in forest soils, Fresenius' Journal of Analytical Chemistry, 367, 467473, 2000.

[9]. T.Q. An, T.P. Huy., N.V. Đông, Nghiên cứu xác định methyl thủy ngân trong bùn lắng bằng phuơng pháp sắc ký khí ghép nối dầu dò huỳnh quang nguyên tử. Tạp chí Phát triển Khoa học và Công nghệ, 16, 2, 53-60, 2014.

[10]. H. Morita, H. Tanaka, S. Shimomura, Atomic fluorescence spectrometry of mercury: principles and developments. Spectrochimica Acta Part B: Atomic Spectroscopy, 50, 1, 69-84, 1995.

\title{
Thiết kế hệ thống sục đuổi và bẫy - giải hấp nhiệt kết hợp sắc ký khí đầu dò huỳnh quang nguyên tử để phân tích siêu vi lượng methyl thuỷ ngân
}

\author{
Lê Thị Huỳnh Mai, Nguyễn Công Hậu, Huỳnh Quan Thành, Nguyễn Văn Đông \\ Trường Đại học Khoa học Tự nhiên, ĐHQG-HCM \\ Tác giả liên hệ: winternguyenvan@gmail.com
}

Ngày nhận bản thảo: 08-11-2017, ngày chấp nhận đăng: 15-05-2018, ngày đăng: 12-09-2018

Tóm tắt-Phương pháp xác định methyl thuỷ ngân được nghiên cứu trên hệ thống sắc ký khí đầu dò huỳnh quang nguyên tử với kỹ thuật làm giàu mẫu là sục đuổi và bẫy. Giao diện ghép nối hệ sắc ký khí và đầu dò huỳnh quang nguyên tử được thiết kế lại dựa trên hệ thống đã có sẵn tại phòng thí nghiệm. Các thông số vận hành của toàn bộ hệ thống được tối ưu hoá và hiệu năng phân tích của hệ thống được xác nhận bằng giản đồ kiểm soát chất lượng về độ nhạy. Phương pháp này khác biệt so với các kỹ thuật khác do nó không cần phải chiết bằng dung môi các hợp chất thuỷ ngân hữu cơ ra khỏi dung dịch nước mà chủ yếu dựa vào sự bay hơi nhanh chóng của nó thông qua phản ứng hoá học ngay trong ống impinger. Một lượng nhất định methyl thuỷ ngân được thêm vào bình sục mấu chứa sẵn khoảng 100 mL nước. Hợp chất methyl thuỷ ngân khó bay hơi sẽ chuyển thành hợp chất ethylmethyl thuỷ ngân dễ bay hơi bằng cách cho phản ứng với sodium tetraethylborate tại môi trường $\mathrm{pH} 5,0$ tạo ra bởi đệm acetate. Phản ứng hoá học này xảy ra ngay trong ống impinger. Hợp chất được tạo dẫn xuất dễ bay hơi này sau đó được sục đuổi bằng dòng khí Ar và được lôi cuốn đến tích góp trên bẫy Tenax trong 30 phút. Kết thúc quá trình tích góp, bẫy được giải hấp nhiệt để dẫn chất phân tích vào hệ thống sắc ký khí cho quá trình định lượng. Giới hạn phát hiện của thiết bị là 4,8 pg Hg/L. Phương pháp có thể được áp dụng để phân tích methyl thuỷ ngân trong các mẫu nước ở hàm lượng siêu vết.

Tù̀ khóa — sắc ký khí, đầu dò huỳnh quang nguyên tử, methyl thuỷ ngân, sục đuổi và bẫy, hàm lượng, thủy ngân siêu vết 